\title{
Heterotopias of (un)desirable bodies: homoeroticism, old age and other dissidences
}

\section{Daniel Kerry dos Santos}

Graduate Program in Psychology, Centre of Philosophy and Human Sciences, Federal University of Santa Catarina, Florianópolis/SC, Brazil

Mara Coelho de Souza Lago

Interdisciplinary Graduate Program in Human Sciences, Centre of Philosophy and Human Sciences, Federal University of Santa Catarina, Florianópolis/SC, Brazil

\section{Abstract}

This paper problematizes some possible stylizations of bodies that are socially perceived as "old" and that are engaged in (homo)erotic activities. We present some "scenes" that were mapped during participant observations conducted in a territory of sociability attended mainly by older gay men. Ways in which the materiality of the bodies in these encounters may acquire other "contours" and new "porosities" are discussed. This rematerialization enables some individuals to resist some models that normalize subjectivities and and bodies. At least at the moment of the parties in this territory (in that queer time and space), the old gay man is no longer a "bicha velha démode", but rather a subject of desire and a desiring subject. Our cartography tends to denounce the fragility and the fictional aspects of homo/hetero/agenormativities.

Key-words: old age, body, gender, (homo)sexuality, (homo)eroticism

\section{Resumo}

Este artigo problematiza algumas estilizações possíveis de corpos ditos "velhos" e em experimentações (homo)eróticas. São apresentadas algumas cenas cartografadas a partir de observações participantes realizadas em um território de sociabilidade frequentado principalmente por homens mais velhos. Discutimos alguns modos pelos quais a materialidade dos corpos nesses encontros passa a ganhar outros contornos, de modo que algumas vidas, a partir do incômodo de um fantasma de abjeção, possam resistir a certos modelos que normatizam subjetividades e corpos. Pelo menos nos instantes das festas que ocorrem em tal território (naquele tempo e espaço queer), o gay velho não é mais a "bicha velha démodè", torna-se um sujeito do desejo e desejante. As cartografias insinuam uma denúncia sobre a fragilidade e o caráter ficcional das homo/hetero/idade-normas.

Palavras-chave: velhice, corpo, gênero, (homo)sexualidade, (homo)erotismo 


\title{
Heterotopias of (un)desirable bodies: homoeroticism, old age and other dissidences
}

\author{
Daniel Kerry dos Santos
}

Mara Coelho de Souza Lago

\section{Preamble}

The Jardim dos Ursos (Garden of the Bears)' is charged with peculiarities. With an aesthetic that purposely varies between kitsch and tacky and with the "rustic" air of a shack, it composes a territory that is rich in details and curiosities. The ambiguity is present right at the entrance. The front of the location appears to be "disguised" and does not call attention to passersby on the street. The only sign that indicates that it is a bar is the sporadic presence of a banner, with the name of the place. It looks like an ordinary house, with a garage in the back that leads to the entrance of the bar. During the day, in front of the establishment and on the same lot there is a tire-repair shop, reinforcing the "rustic" nature of the environment while alluding to an erotically fetishized imaginary related to virility. Upon entering, one passes through a small hallway with photos of clients exhibited on the wall. Along this small walkway there is also a collection of used clothes from the bar's thrift shop. At the end of the hall we usually find the owner or an employee receiving customers and giving them order slips. Upon entering the bar itself, people find themselves in an atmosphere quite different from that in front of the old house and at the tire shop. The decoration is startling. The walls and all the corners of the room are covered with objects like urinals, old typewriters, stuffed teddy bears, miniature objects of all kinds, the head of an ox, a fireplace, rustic cabinets, old telephones, horns, framed posters from old movies, chintz fabric covering the walls and some tables. There are so many objects that at times new visitors spend some time in the first area just to take in the exotic and cheerful decoration. The bar is divided into a few inter-related spaces. A dance floor is right next to the bar, an area with more light and tables where people drink, talk and play pool. In the back there is a garden and an open space and farther behind the garden a nursery where the owner raises pheasants, ducks and chickens. Access to the nursery, however, was closed during the year 2011, and customers could only circulate in the covered portion of the bar and a small part of the garden. The portion of the garden and of the animals, when it was still accessible, seemed to always be a source of surprise, laughter, and at times annoyance for some customers. Some see the animals humorously, others with disdain. The fact is that most people seem to think: "I never thought I would see ducks at the party!" as some clients said. The back of the bar (garden and nursery) was also an area for "pick-ups," a place of fleeting sexual encounters between clients who may have met during the party. In addition to the unique aesthetic, the arrangement of the environments is constantly changing. Since I began to frequent the location, nearly each time I arrived I found a new arrangement, an innovation in the decorations, something new, even if subtle.

$[\ldots]$

1 This is a fictitious name. 
I circulated through the space closely observing what, to me was becoming very clear: the presence of older men stands out at these parties and the appearance of a complicity among all of them gave me the impression of a moment of collective fraternization among "old friends." This mood may seem obvious for a location where people go to have fun with friends and to meet people, but something seems to distinguish it from other parties and clubs that have a predominantly young public. There is a more intimate atmosphere, although no less festive, one that is vibrant, with lots of conversation, laughter and a tone of relaxation.

(passages from dos Santos' field notes)

These two field diary excerpts were produced during a graduate study in psychology that proposed to map modes of stylizing male homoeroticism ${ }^{2}$ in old age. The field study took place in a bar considered "marginal" in the circuit of homoerotic sociabilities 3 in the city of Florianópolis, Santa Catarina in Southern Brazil, known as a "Bear Bar"4. One of the authors of this article attended the bar for more than a year and participated in the "Bear Encounters", thematic parties that were held monthly at the locale.

In our research we followed the "principle of cartography" as a methodological guide, as suggested by Deleuze and Guattari (2009). The principle of cartography guides a perspective and a mode of sensibility for accompanying processes and flows in movement in the social field (Kastrup 2009). Therefore, there was no intention to seek a fixed and univocal representation about homoeroticism in old age, but singularities and fissures that in a certain way challenge the hegemonic field of representations. We add to this principle of cartography our experience in the anthropological and ethnographic field, with participant observation, the production of field diaries and exercises in estrangement in that which was familiar to us, as suggested by Brazilian anthropologists (Da Matta 1978; Cardoso de Oliveira 1998; Fonseca 1999). Authors such as Virgínia Kastrup and Laura Pozzana de Barros (2009) emphasize that in some aspects cartography approximates to ethnography, because among other presumptions, it also requires inhabiting a non-familiar territory. In this sense, the cartographer, like the ethnographer, goes to the field to experience relations, ways of life and an entire network of significations and affections produced in a collective.

There has been a recent flurry of research on homoeroticism among older men. In his thesis about "male homoeroticism and aging," anthropologist Carlos Eduardo Henning (2014) affirms that none of his interlocutors (elderly gays) identified themselves as a bear or attended bear circuits of sociability.

\footnotetext{
2 In our article, when we refer to male homoeroticism we are referring to eroticism among cisgender men, that is, men who recognize their gender identity according to the gender that was attributed to them at birth. The category cisgender has been requested and problematized above all among transfeminist movements, both in Brazil and in international contexts. We use this analytical category in our text, because we understand that it denaturalizes gender identities (cisgender identities) that are used as references of what is supposed to be the gender "normality."

3 Other studies that are dedicated to the study of homoerotic sociabilities and or LGBT groups (lesbians, gays, bisexuals, transvestites/transsexuals/ transgenders) in Florianópolis and the region can be found in Perucchi (2001), Vencato (2002), Silva (2003), Córdova (2006), Henning (2008), Cardozo (2009) ,Amaral (2012) and Santos (2012).

4 Bears is an identity category that refers to men who are usually (but not necessarily) fat and hairy. In addition to these bodily attributes, there also appears to be among "bear communities" a standard of gender that, according to Fernando Pocahy (2011), exalts a virile masculinity that can inhabit these bodies. Pocahy (2011: 38) also affirms that the bear communities operate "as a form of 'identity regime' that questions the 'gay' regime of the body and of standardized sexual practices." As can be noted based on the very name given to the parties (Bear Encounters) and from the conversations with the interlocutors during the field research, the term "Urso" or Bears"' refers to a native category that is shared and understood by the local attendees.
} 
Meanwhile, in the thesis in the field of education by Fernando Altair Pocahy (2011), who analyzed forms of regulation of gender and sexuality in intersectionality with age and problematized the discourses of objectification aimed at elderly men who exercise homo/erotic practices, the author explains that part of his field studies were conducted in bear locations. According to Pocahy (2011), the men with elderly, fat and hairy qualities come to identify with the bear community, although these are not the only aggregating qualities of these communities. Isadora Lins França (2010) studied the segmentation of the GLS market and some spaces of (homo)sociability in the city of São Paulo, where she also identified locations of interaction between people who identify themselves as bears, senior and or older gays. Another author who discusses the sharing of spaces of sociability between bears and seniors was Júlio Simões (2004), who also analyzed circuits of homoerotic interactions in the city of São Paulo.

We consider that many territories of sociability of older gay men ("mature" and or "seniors"), function, therefore, based on different interactions, configurations and territorial codes (Perlongher 2008) that can vary according to the region of the country and city, the access to these spaces, their relations with the city, and other factors. It is important to highlight that in these territories we can see various forms of production and reinvention of bodies, of desire and of eroticism. It is in these spaces, which are generally considered marginal in the hegemonic gay scene, that a sexual and erotic micro-politics is put in motion, potentially questioning a "sexopolitics" (Preciado 2011), even if within these spaces normative regimes referring to gender and sexuality can be reiterated and reproduced.

We chose to carry out our research in the Bear Garden because it appeared to be an alternative territoriality to more hegemonic gay spaces of the city, in which circulate eulogies to certain types of bodies considered to be legitimate. As a possible space of being for subjects who are in discord with certain aesthetic, age and sexual norms, the bar in question emerges as a territory that potentially moves other erotic and desiring flows.

Although it is a territory that intends to exalt the so-called "bear culture" and the sociability of subjects who identify with this community (both the bears, as well as their admirers, the bear lovers or chasers), it can be perceived, based on field observations, that the people who frequent the location see themselves as older, mature and or senior ("coroas", in Portuguese) gays. ${ }^{5}$ Although most are older men, there are also younger men who have emotional and sexual interest in the older ones. The bar is therefore a place for intergenerational emotional-sexual encounters, as we discussed on another occasion (Santos and Lago 2013).

The "bear appeal" given to the bar was evident from the decoration of the space, the flyers for the parties and the Facebook page, all of which which serve as means for promotion. Nevertheless, the public that frequents the location does not necessarily completely identify with this identity category. In this territory, the categories bear and old/senior at times blend and wind up representing the same individuals, although some of them only recognize themselves as "bears," others only as "mature" or "older gays" and others do not identify with either of these identities. This is not to say that in all the territories of sociability of bears we will find older gay men, or that older gays necessarily identify themselves as bears. This "identity combination," - or even this blurring of identities - appeared to us, however, to be outstanding in the bar where the study was conducted.

We would like to make an addendum in relation to some analytical categories and native categories. We use the term homoeroticism in agreement with Jurandir Freire Costa (1992) who affirms that this concept allows a more flexible understanding in relation to the plurality of sexual practices and desires of people who are sexually oriented towards people of the same sex (and or, we also add, of the same gender). The

5 The categories "bear lovers", "chasers," "older gays," "mature" and "coroas" [seniors] are all native categories that were heard in the field research. 
concept of homoeroticism aims at an understanding focused less on identity that is more open to the possibilities of problematizing the multiple ways in which individuals involve themselves in sexual-erotic relations, without their practices necessarily being tied to the affirmation of (or identification with) a specific sexual identity (gay or bisexual for example). We also do not ignore the categories "homosexual" and "homosexuality" that as Foucault (1988) presented, refer to the production of a modern discourse that is consolidated based on the dispositif of sexuality. We consider, however, that contemporarily the category "homosexuality/homosexual" can situate individuals from a position of political affirmation and or as a position from which an individual can recognize himself or herself as a subject.

These distinctions, even if subtle, function as analytical and problematizing operators, but we emphasize that they do not necessarily involve native categories that are mobilized and shared among our interlocutors. Categories such as "gays," "seniors," "mature", "bears", "bicha" [+|-fairy], "viado"[+|-fag] and even "homosexual" or "bisexual", can find resonance in a broader social discourse, but can also acquire particular senses and meanings that need to be located in the context observed. We heard from some of our interlocutors, for example, affirmations such as: "I am a hetero who likes boys [...], a man who likes other men"; "I like to come to this bar because the people here are more discrete, there are no flaming fairies"; "other bars in the city have lots of fags"; " my friends of my age are more reserved." These identity representations (of oneself and of others) that arise in the narratives heard carry perceptions about the experiences of homosexuality that can cross with other experiences such as, for example, generation, social class and gender. These categories also operate a logic of differentiation in relation to other gay groups and to other spaces of sociabilities, using as discursive strategies those ranging from practices of resistance to the reproduction of more pejorative concepts in relation to other expressions of sexuality and gender. It is therefore worthwhile to consider these categories of articulation for a deeper understanding of the experiences. It is in this sense that for Avtar Brah (2006), it is important to analyze the constructions of the theories as relational and contingent phenomenon. It is, he argues,

better to construct them as historically contingent relations specific to a given context. From there we can focus on a given context and differentiate between the demarcation of a category as an object of social discourse, as an analytical category and as a theme for political mobilization, without making suppositions about its permanence or stability over time and space (Brah 2006: 353).

With these considerations, we would like to indicate that in our studies we have sought to articulate various categories, whether as objects of social discourse (as we can see, for example, in the social discourses that produce the figure of the "elderly" and of the "Third Age," homogenizing the experiences of older people); analytical categories (as we exemplified above based on our positions concerning the possibilities for problematizing contemporary expressions of eroticisms and sexualities); or as categories of political mobilization (as we see in identity movements, such as the LGBT and bear movements, etc.). These categories cannot be taken as separate, static and essentialized points, because they are constantly articulated in narratives and experiences, modulating discourses, practices (of resistance and subjection), performativities, and presenting a particular regime of signs that construct a system of codes that can be shared among the local collective. 
In this article ${ }^{6}$ we will focus our discussion on the immanent relationship/production between territory, body (homo)eroticism and desire and their assemblages ${ }^{7}$ in a territory of sociability of subjects considered to be dissidents ${ }^{8}$ in the hegemonic erotic landscape of the city. For this reason, we describe some passing scenes, moments and conversations that affect the look, the body and perception of one of the authors during the cartography traced in his study.

\section{Scenes of a heterotopia}

What can a territory do? What can the inventive potential of a space do? How do a space and a territory allow (re) significations of (homo)eroticism in old age and (re) inventions of bodies (old or aging) shadowed by the phantom of abjection and allocated to the margins of a field of intelligibility and legitimacy? To begin our discussion about these questions, we would like to present two scenes recorded in field diaries. ${ }^{9}$ These scenes described fleeting moments that operate as analyzers in our cartographies. The episodes took place on different days, although both took place during parties called "Bear Encounters." The first scene was in December 2010 and the second in January 2011.

\section{Scene l:}

\section{The night of the go-go-boy}

The last Bear Encounter of the year was held on December 11, 2010. At this time, the attraction of the party would be a go-go boy who would perform sensual dances. I thought the presence of this character from gay nightlife to be strange, given that he sexualizes and emphasizes muscular bodies, in a space where this hegemonic aesthetic does not appear to be the strongest ideal, or the most desired. After my customary circulation through the bar and some conversations with some customers, the owner of the bar announced that the boy was present and that everyone should come close to watch him. With the announcement, some

6 Part of this article was based on a text published in the annals of the VI International Congress of Studies about Sexual Diversity and Gender of the ABEH (2012), where we presented some initial reflections of our research.

7 Assemblage (the English translation of the concept in French of agencement) is a concept used by Gilles Deleuze and Félix Guattari. According to Graham Livesey (2010:18) in the book "The Deleuze dictionary", “assemblages, as conceived of by Deleuze and Guattari, are complex constellations of objects, bodies, expressions, qualities, and territories that come together for varying periods of time to ideally create new ways of functioning. Assemblages operate through desire as abstract machines, or arrangements, that are productive and have function; desire is the circulating energy that produces connections. An assemblage transpires as a set of forces coalesces together, the concept of assemblages applies to all structures, from the behaviour patterns of an individual, the organization of institutions, an arrangement of spaces, to the functioning of ecologies [...] An assemblage emerges when a function emerges; ideally it is innovative and productive. The result of a productive assemblage is a new means of

expression, a new territorial/spatial organisation, a new institution, a new behaviour, or a new realisation. The assemblage is destined to produce a new reality, by making numerous, often unexpected, connections".

8 The word dissidence has its etymological origin in the Latin verb dissideo, which means "to remain distant; to be separated.” We consider as dissident bodies (or even dissident eroticisms and sexualities) those bodies that contest (or escape and or distance themselves) from regulatory norms and ideas that produce corporal materialities considered legitimate and intelligible. The dissidence, in this sense, is effectuated in the production and affirmation of other possibilities for ways of life, challenging some hegemonic representations that authorize and or unauthorize bodies in their multiple forms of expression. and circulation

9 Since the scenes reported are excerpts from the field diaries produced by one of the authors, Daniel Kerry dos Santos, they will be presented here in the first person singular. The second author, Mara Coelho de Souza Lago, is dos Santos' thesis supervisor. 
people gathered around the performance space, including myself. The show began and I counted that only eight people were close to the stage. A few minutes later, a larger group came around, took a look and went back to where they were, at the tables, talking and playing pool. Everyone was congregated in the space away from the dance floor, not appearing to pay the least attention to what was happening in that space. The small group that was still close to the show spoke among each other, some with their backs to the go-go boy. Every once in a while these clients would take a look and seemed to make a comment about the dancer. Nevertheless, they also soon appeared to get tired of the scene and went to where most of the people from the party were. The onlookers abandoned the performer who was left dancing alone, exhibiting his apparently uninteresting body, but doing his job. During the night, the boy returned to the stage a number of times, but without much success or interest from the people. Based on this scene, I began to perceive that most of the time the dance floor was empty and that the people seemed to prefer the tables, where it was easier to talk. The dance floor appeared to be a representative sign of parties attended by younger people - many nightclubs only have a dance floor - while, in that space, it was only one of a number of environments that did not appear to be very attractive to the clients.

(passage from field diary, December 2010)

\section{Scene II:}

The go-go-bear's turn...

The first Bear Party of the year was held on January 8, 2011. This time, the attraction would be a go-gobear. I was very curious to know what this was, because I had never heard of this type of performer. The association was obvious: a go-go-boy who was a bear"! I thought this was interesting, after all, the presence of a "traditional" go-go boy at the last encounter had "disturbed" me. I went to the party, with great curiosity.

The go-go-bear's show was about to begin. I went to the dance floor, in the middle there was a small stage for the go-go bear to dance. This time, the show was very different from that of the go-go boy. The floor filled up, everyone went to see the performer, who was applauded and watched desirously by some. The performance was made by a fat man with a classic "bear style" and an appearance I considered very handsome. With the music playing he removed his pants and danced in his underwear and a tee-shirt and stayed that way until the end. The dance, the gestures, the steps were made the same way that the "traditional" go-go boy did. The difference was the corporal aesthetic and what was being produced based on that dance. A body that in another context would be seen as uninteresting, de-eroticized or that would be disdained and inferiorized by a dominant aesthetic, there, in his performance, was a producer of sensuality and seduction. It was a resignified body. The go-go bear, moving as sensually as he could, generated an eroticism to a public that shared the same signs and the same marks. He also insinuated himself with other people (non-bears) who considered the bear-body desiring: young, old, thin, mature... The erotic dance was performed for a few moments and stopped when the performer got tired. In these brief intervals, he drank some water and rested, but remained there among his public and interacted with other men, slipping among the bodies. After recuperating, he returned, danced some more on his ministage and the show continued.

(passage from field diary, January 2011) 
These two scenes are emblematic of the desires and erotism in the bar. The lack of interest in the go-go boy and his conventional aesthetic shows that the people present in the bar resist these his appeals, returning to that which was really giving them pleasure: the potency of those good encounters that flowed from a distinct aesthetic. Of course desirous looks were aimed at the go-go boy's body, but from a minority. This kind of eroticism did not appear to seduce them, it was not capable of shifting their attention and hypnotizing their bodies. The go-go-boy body came to be just a decorative body in the space.

Meanwhile, the performance of the go-go-bear was received as a desirable and erotic body, celebrating a transgressive hedonism. For Preciado (2011: 14), this "deterritorialization" of the body supposes a resistance to the process of becoming "normal." The processes of normalization and homogenization of bodies, typical of our society and of the effects of biopolitics, can be, at times like those of the scenes described, questioned and confronted. The go-go-bear, who perhaps does not gain erotic legitimacy in other contexts, composes another route for desire. This appears to be possible, because according to Preciado (2011: 14),

$[\ldots .$.$] the fact that there are precise technologies for the production of "normal" bodies or for the normalization$ of genders does not give rise to a determinism or the impossibility of political action. To the contrary. Given that the queer multitude carries within itself, as a failure or residue, the history of the technologies of normalization of bodies, it also has the possibility to intervene in the biotechnological dispositifs for the production of sexual subjectivity. [emphasis ours].

That is, the political action of these deviant bodies (bears, old men, old-bears, coroas) takes place precisely at the time of another desiring and erotic production, which runs through the territory in a direction counter to the biopolitical technologies that organize the body of the populations.

We also believe that it is important to emphasize, also in agreement with Preciado (2011), that this multitude is not constituted as a reserve of transgression within the social field, because it does not manifest fixed resistance and transgression, but a micropolitical movement that can rapidly crystalize. It is also not something opposite to the identity strategies and logics that capture and territorialize bodies, because the dominant identities that normalize "being gay" and "being old," need their opposites to exist. In other words, the old gay, who materializes the exterior that is constitutive of or abject in relation to what would be a "normal gay," and/or a "normal old man," maintains the very fiction of the normality of these identities, giving them an aura of cultural intelligibility (Butler 2002a).

These scenes raise various questions. One of them is "what produces a desired/desirable body?" And "what does a desiring body - or a body that desires, produce?" And more, "what contours (or non-contours) does eroticism acquire from the deterritorialization of bodies and desires that become organized or unorganized". These other desiring forms that are related to an event that breaks out within a multiplicity, are not reduced to a unit or a subject. This is important to emphasize, given that we are not relating desire to an interiority, an individuality, something closed on itself. Desire here is being considered in its productive dimension, of flows and vibrations, which run through environments, always nomadic and migrant (Deleuze\&Guattari 2010:386). In this sense, we do not intend to affirm here that the people present there also do not feel pleasure and attraction for those toned, young idealized bodies. Indeed, we heard from some clients of the bar that they also feel sexual attraction for younger men with whom they can relate. We discussed the possibilities for intergenerational homoerotic relationships which we observed in the bar (Santos and Lago 2013). In fact there was no specific restriction in relation to the age of the possible romantic and or sexual partners, although some expressed an exclusive preference for younger men and others preferred people of the same age, as one interlocutor reported: "I would like to meet someone older, because I have suffered many deceptions with younger boys, because they really do not know what they want." 
But they feel more than that, because desiring machines are established in the territory. These machines operate a system that cuts off the flows of the daily ideals and connects them to other machines, thus extracting other currents of aesthetic and erotic flows. The production of desiring bodies, in this sense, is an effect of a movement of the multitude and not of isolated individuals captured by a homogeneous and serialized form of desiring and feeling.

These other modalities of perceiving an erotic body and its other desiring productions are directly related with what Néstor Perlongher (2008) calls territorial-codes. For Perlongher (2008) some territories are able to produce other internal flows and codes that signal other possibilities of subjectivation. These territories, like the bar we studied, invent other fictions about the body and about eroticism, so that new perceptions, sensibilities and affections can be activated, producing another erotica. This is not a case of romanticizing a territory that is not affected by the social surroundings that prescribes norms, models and standards, but of considering that based on these differentiations presented by the territorial codes, it is possible to see other (micro) politics of the body in motion. Richard Miskolci and Larissa Pelúcio, commenting on Perlongher's concept of territorial codes, indicate:

[the internal codes] maintain their ties with the "normal" universe and do not create "autonomous systems of sociabilities," but a subterranean way of life. This can be synthesized in the Deleuzian proposal of lignes defuite, which Perlongher characterizes as a social zone in which control is looser, but not completely suspended, given the limbo character between the traditional and something diverse, to which its participants respond according to the demands, flirting once with one, then with another, but without completely adhering to either of them.

(Miskolci \& Pelúcio 2008: 16)

The desiring production, an effect of these machines moved by these flows and codes, is simultaneously the very social production of the territory. For Deleuze and Guattari (2010), social production and desiring production are the same thing, they are a relationship of immanence and of processuality. This appears to be the case of the scenes we described. The social production that invents a territoriality that congregates a multiplicity of people (and creates an ursine culture or a territoriality of old gays, for example) is capable of producing another form of bodily relationships and encounters. The territory is shaped precisely by the assemblages of desire present there, at the same time in which other desiring forms are produced precisely by the existence of the territory. According to Benevides (2009), the constitution of the territories is brought about by assemblages, so that we can find two lines of collective assemblages: the collective assemblages of enunciation and the machinic assemblages of desire.

If the collective assemblage of enunciation comes to affirm that the linguistic production of enunciation is not focused on the individualized subjects, the machinic assemblage of desire comes to affirm that desire is an economy of flows, it is neither interior to a subject nor does it tend toward an object, because it is process (Benevides 2009: 213-214).

Thus we consider the territory to be a location invented and moved by these assemblages, which are decentered from an individual subjectivity and from a totalized desire. They involve a proliferation of desiring-machines, in which desire produces the social and vice-versa. A "new" aesthetic and ethic thus become possible, pointing to technologies of the self that recompose other corporalities, that is, which create forms of stylizing bodies, producing desiring modes, expanding universes and territories and inventing ways of life. All in a flow that crosses and constitutes the local reality.

These two scenes make visible how the bodies in encounters produce modes of subjectivation. Here we follow a lead from Guattari (1992: 161) who suggests that to conduct a cartography of the productions of subjectivity it would be necessary to turn to the complex aesthetic affects. These affects, in this case, 
moved by the unusual dance of a singular body, and by the proliferation of other modes of perceiving corporality and the erotic, constitute not only that instant, but also a moment of subjectivation. The bodies are affected by other forces, bend and avoid power and create a relationship of pleasure among themselves. Erotic pleasure, but also the pleasure of friendship and of the opportunity for a practice of freedom where wrinkles and white hair and the signs of time that mark these bodies do not establish an hierarchical and depreciative relationship, at least in the moments that mark the time of the territory. To the contrary, they become, based on another aesthetic valuation, an element of what one can be proud of, exhibit, touch, excite, appreciate, enjoy. New corporal shapes gain importance. The territory, in this way, constitutes itself as a place for practices of freedom, given that it appears to present individual and collective subjects a "field of possibilities, where various conducts, various reactions and various forms of behavior can occur" (Foucault 1995: 244).

\section{Heterotopia as a productive affirmation of an erotic difference}

The clients we talked to did not seem to go to the bar to look for what they can find in other places, such as bodies shaped by fashion shows and in exhibition. They seem to look for the opposite, a material reality that escapes the prerogatives of the beautiful body (in its more normative definition of the term). They are bodies that discover new trajectories in the circulation through the city and give way to movements of desire that request other forms of expression. A eulogy to deviation: to the fat, the old, the hairy, the ugly, the poor and to the rich who romance with each other. The owner of the bar, upon speaking about the public who attends his establishment, raises these issues:

[...] it's kinda like this, I'm not ridiculing my little bear friends, its quite clear. But they say to me: "At what party am I going to feel comfortable? Bald, hairy, fat, ugly, old!" And I say: "Gee, I'm like that too! I'm like that." So they say:

'Hey, here we feel good, because here everyone gets together. The bald, the hairy, the ugly get together...

It was in this context of interaction of dissident bodies, therefore, that we could accompany erotic and romantic experimentations between old men and other old men or with young men. The segmentarity, in this case, becomes flexible and allowed affection between and the encounter of bodies that were once distant in the erotic geography of the city. The researcher's body, which was also eroticized in that location where age classifications do not necessarily establish an insurmountable barrier for relations, was often the target of erotic and sexual advances from many men of a wide variety of ages. We realized that the materiality of the bodies in these encounters came to take on other shapes and new porosities, in such a way that some lives, based on the disturbing phantom of abjection, could resist certain normative models. At least at the moments of the parties that take place in that territory, at that queer time and place, to use Halberstam's terms (2005), the old gay is no longer the "old démodéfag," he becomes a subject of desire and desiring, eroticized. The bodies, enjoying certain erotic landscapes, fold upon themselves (Guattari 1992) and are affected by a heterotopia (Foucault 2009), an other space, where the possibilities of subjectivation are effectivated in the real field of the materialities of bodies and of territorialities.

But what territory is this? What bodies are these that mutually affect each other and create another zone of possible intensity? We believe that we were immersed in what Foucault (2009) termed heterotopia - an other space. It is a territory that creates other utopias for the body. By conducting a cartography of this different space, we accompany moments/scenes of those bodies that enjoy an aesthetic that challenged a certain ideal of the biopolitical utopia. The bodies of this biopolitical utopia that are materialized based on 
the matrices of the intelligibility of gender and sex (Butler 2002a, 2003) constitute the regulatory ideals that these dissident bodies constantly confront in a continuous conflict of aesthetic resignifications. In terms of the utopias of the bodies, Foucault (2010: 01) asks:

To what is due the prestige of utopia, of beauty, of the wonder of utopia? Utopia is a place outside of all places, but it is a place where I will have a body without a body, a body that will be beautiful, limpid, transparent, luminous, fast, colossal in its power, infinite in its duration, turned off, invisible, protected, always transfigured; and it is quite possible that the first utopia, the one that it is most difficult to extirpate in the heart of men , might be precisely the utopia of a bodiless body.

Some utopias of the body, in this sense, are founded upon the very body of the biopolitical project that, as Francisco Ortega (2008) discussed, fastened in a bio-aesthetic process, seeks to attain a state of unattainable perfection. For Fernando Pocahy (2011b: 207)

The complete, fast, dynamic body is the body of the biopolitical utopia of the modern Project, a body that is not in fact attained. It is a 'planned' body, designed, calculated, measured, fictioned. The body is a political fiction, forged, woven in the dispositifs of gender, sexuality, age, size, shape, weight, 'race'...

This project of an "impossible" or "unreal" body constructed by modern dispositifs, can trigger an ethical conflict in the relation of an individual with himself. For Foucault (2010: 04) "utopias are born from the body itself and later, perhaps, turn against it".

But how can these utopias of the body turn against their own materiality? For Butler (2002a), the materialities of bodies are not a static and simple reality, but are constituted through processes of the forced reiteration of norms. When we encounter the body of an elderly gay man, for example, we perceive we are facing a forged materiality in a field of sexual, gender, generational, age-biased norms. These norms, effects of certain enunciations and of power relations, govern the materialization and the signification of the bodies. Materiality, however, as a discursive effect, is never complete and finalized, but is involved in a constant performative process. Thus, for Butler (1993:2), "it is the instabilities, the possibilities for rematerialization, opened up by this process that mark one domain in which the force of the regulatory law can be turned against itself to spawn rearticulations that call into question the hegemonic force of that very regulatory law". The materiality, in these terms, cannot be understood here as something beyond or outside of the discourse. Corporeal materiality itself is an effect of power and of performative acts, that is, of reiterative and referential practices through which discourse produces the effects that it names (Butler, 1993). The regulatory norms of sex and of the dispositif of age regulate the production of performative experiences of sexuality and of aging. The heterosexual imperatives and those of youth are articulated and produce a abject constitutive exterior with which the old gay man appears to be identified. The biopolitical discourses about the body of the heterosexual youth (and also of the homosexual youth, in some contexts), turn against the aged bodies, reiterating even more the norms that define the fields of cultural intelligibilities and legitimacies. We are thus facing a paradox of subjection, which for Butler (1993: 3), establishes the contradiction that the subject who should be opposed to norms that subjugate him, is produced by these very norms. We see, in this way, that the regulatory ideas that confront the utopias of the body and that regulate the performativities, in some moment, sooner or later, turn against the same bodies with the force of exclusion and abjection.

But despite the insistencies of the norms, which are perpetuated through performative acts, it is possible to find gaps and fissures in these territories that constitute heterotopias. According to Pocahy (2011) subversions of the norms are possible in particular and provisory moments. 
Even if a norm carries within itself the idea of perenniality, being elaborated to maintain itself stable, this constant is never attained. At some moment the norm fails. It always fails. And new games of power are established and a certain margin of freedom can be opened. (Pocahy 2011: 72)

Since at each dissolution of a utopian body other utopias are established (therefore, effectively materializable), there is no way to escape this. "For me to be utopia, it is enough that I am a body," (Foucault 2010: 04). Thus, the creation of the new corporalities is possible when, interpellated by a heterotopia, the body is affected by other forces, is composed by other relations, stylizes other movements, desires other modes. This is because this heterotopia, in opposition to the positions/spaces of biopolitical projects, creates conditions for ways of life that are created in the daily experience of the subjects, with the vibration of bodies in real encounters, whether they are erotic, affective, sexual or friendly. Thus, for Foucault:

There are [...] real places, effective places, places that are delineated in the very institution of society, and that are types of counterpositionings, types of utopias that are effectively realized in which the real positionings, all the other real positionings that can be found at the interior of the culture are at the same time represented, contested, and inverted, types of places that are outside of all the places, although they are effectively localizable. These places, because they are absolutely different from all the positionings that they reflect and of which they speak, I will call, in opposition to utopias, heterotopias [emphasis ours] (Foucault, 2009)

The bodies of the old gays and of the bears (who in the case of our study often ended up merging) come to function as desiring machines, at the interior of that which Foucault (2009:416) calls heterotopia of deviation, "the individuals whose behavior deviates in relation to the average or the required norm are located". The deviation, in this case, is located in a multiple path. In relation to the dispositif of sexuality, it deviates both from normative heterosexuality and from the established gay way of life imbued with its (homo)normativities reinforced by the media (such as television dramas, magazines, music, etc.) and by certain gay groups who occupy a privileged class position. In relation to the dispositif of age (Pocahy 2011), it deviates from the medicalized, normalized, controlled and hygienicized age. These bodies that insinuate themselves erotically in a field of deviation can be seen, according to Beatriz Preciado (2011), as political potency and not simply as passive effects of the discourses about sex or of the dispositif of sexuality. In this sense, biopolitical statements come to be questioned based on the materiality of the body itself, which deterritorializes and opens up other possibilities for pleasure and eroticism.

The heterotopia of the deviation which is composed in this territory also displays a relationship with time (as in a queer time, in the terms of Halberstam (2005)) in its most fleeting form, marking a rhythm in a countertime of the ordered steps that guide the daily movements of the bodies. During the parties, the researcher found himself in a heterotopia that encompassed a time for friendship, for relaxation, for leisure and for the pleasure of dissident bodies. In the words of Foucault (2009: 419), they were those heterotopias that "are connected [...] to the time in which he has for the most futile, most fleeting, most precarious, and this in the form of a party. They are heterotopias that are no longer eternalized, but absolutely chronic." 


\section{Some considerations (in the wake of the dissidences)}

The old gay may appear to be allocated in a very uncomfortable zone of tension: among the old heterosexuals he is not "noticed" or, at most, is integrated or assimilated into a network of sociability in which questions related to homoeroticism should be hidden. ${ }^{10}$

Meanwhile, among the younger gays, he is avoided, rejected, inferiorized, and ridiculed. It appears to us that among the older heterosexuals and among the youngest gays, the old homosexual is unthinkable, ${ }^{11}$ as if he was found at the limit of the terrain of intelligibility, based on a phantom of abjection and exclusion (Butler, 1993). But we prefer to be more cautious in terms of the affirmation that abjection is the "destiny" of these subjects. In this discussion it is important to problematize the notion of abjection, as proposed by Butler (1993). According to this author, the definition of what is or is not an abject body/being is not the most appropriate question. This is because this demarcation would create an ontological domain immediately regulated that would require exclusions to maintain itself (Butler 2002b). In this way, it is not up to this discussion to define what would be a "homosexual old age," or if old gays are abject or not. These categorizations will always be inadequate, considering the multiple and heterogeneous ways of life that different subjects can create and incorporate in their existences. We consider quite provocative the suggestion made by Vitor Grunvald (2009) when problematizing a "politics of abjection" where the abjection can be insinuated as a production instead of being thought of as a lack, a "something" that cannot access the symbolic or that would establish fields of cultural legitimacies. According to Grunvald (2009: 50) abjection would be "a plane of productive and affirmative differentiation: it is not a question of still not being different, but of always being different from oneself'. From this perspective, we risk thinking that those dissident bodies that circulate in theterritory we have described produce and invent difference based on the movement of another politics of eroticism (and of the body), that affirms and experiments deviance, the

10 The "hiding" of sexual orientation in the case of older people, is often associated to a "return to the closet." In research about the Contexto da SexualidadenaFrança, coordinated by Michel Bozon, in 2006,

it was observed that among men older than 60 the opinion predominated that "homosexuality is a sexuality that goes against nature" (Bozon 2009, p. 165). Moreover, the number of men who have an intolerant attitude toward homosexuality is double that of women, which according to Bozon, may mean "the fear among some men of seeing their male identity questioned.” This data indicates that homophobia appears to be a marked element among older people, which would reinforce the idea/stereotype that an old homosexual would have greater difficulties with socioability and of access to support networks. We highlight that the data presented in the study by Michel Bozon cannot be mechanically transposed to Brazilian realities. We consider it relevant, however, to indicate that the disdain, prejudice and or discrimination against homosexualities is also a recurrent phenomenon in Brazil, as various statements from LGBT movements throughout the country have shown, as well many studies that have been conducted in Brazil in gender and sexualities studies.

11 It is important to consider that the social experiences of aging do not negatively affect only gays, lesbians, transvestites and transsexuals. Aging carries a social imaginary that is at times negative, where the body is represented as decadent, depotentializing and ill, and at other times as positive, as we see in biomedical, pharmacological and marketing discourses that act in the construction of an active aging and of individuals who compose the groups of the "third age." This involves two antagonistic models of understanding the experiences of aging that oscillate between positive and negative representations, as indicated by GuitaDebert (1999). When we emphasize that aging among homosexuals is unthinkable we want to emphasize the need to problematize the experiences of aging based on an intersectional perspective, that considers multiple vectors of oppression acting in the construction of social and subjective experiences. Thus, we have considered that there is a heterosexual matrix that prescribes a margin of intelligibility for aging, as well as an ideal of youth that positively legitimates some experiences of homosexuality. Beyond these vectors, it is essential to consider that the experiences of aging also carry marks of gender, of social class, of race/ethnicity, and others, which produce different experiences that cannot be considered universal and that need to be pondered in their specificities. 
deviant, the deviated. Fernando Pocahy (2011) also questions the discourses that directly associate the aging experienced by gay men to a character of abjection. The author provokes us with questionings that steer us to the affirmation of the potency of eroticism among the oldest gays as a possible experience in the field of pleasures. In the words of this author (2011: 26): "what problems [...] would be raised by the idea of thinking that an old man could experiment with fleeting and risky practices?"

If the abject bodies are abject in their relationship with culture, in what way could the notion of abjection help us to problematize a queer possibility for incoherence and for illegitimacy as routes of transgressions of the norms, even if for fleeting and provisory moments? How, in this case, can these bodies positively affirm deviance? We think that even if there is a phantom of abjection that surrounds those old bodies and those queer desires, the lines of flight do not cease their affectations and to distinguish themselves from themselves. There are many possibilities for folding and unfolding of bodies, which in an unordered movement creates holes, small orifices, porous surfaces that allow openings to other sensibilities and other zones of intensities of the body (Deleuze 2008) that are not those pre-fabricated ones, those prêta-porter identities that mimic the glamour and mediatic clichés (Rolnik 1997). Those beings/bodies, which can be haunted for being in a supposed inhospitable zone of existence, move a micropolitics of abjection that produces another erotic that is excited by other intensities and surfaces.

Based on these aesthetic productions, the researcher himself who frequented the location for more than a year came to be confronted by this new erotica. We believe it is important to emphasize that it is precisely the effects on the researcher's body that allowed him to problematize and "cartograph" this territory of sociability. ${ }^{12}$ The researcher came to recognize the possibility of slipping between other forms of pleasure and friendship. This is because he did not assume a neutral position in the territory, but allowed himself to be affected by those flows that were foreign to him. He did not distant himself from the possibilities of pleasure and fun at the bar, given that he considered that the practice of inhabiting a territory - in this case a territory of pleasure and friendship - implies a personal experience, in direct contact and in an affective involvement with the people, with the space and the territory. There was also no concern about maintaining a neutrality, an objectivity, a descriptive scientism, but with establishing an opening to new intensities and perhaps even for learning: looking, listening and writing, as proposed by Roberto Cardoso de Oliveira (1998), and in this way learning what those subjects had to say, what those bodies could enunciate and how they would move. We did not deny a possibility for an identification process between those people and the researcher. They are subjects that share an experience of pleasure and identity that is similar to that which the researcher experienced and assumes. It is as if, embarking into these territories, it was possible to problematize the very existence, the very body that is transformed with time, the very forms of desire and the very historical and cultural contingence of that which is perceived as "erotic." After all, it is not possible to be completely free of the same normativities and the same phantoms of abjection that circle our

\footnotetext{
12 It is in these movements of affectation and in these experiences where difference is made present in the encounters of the bodies that a form of doing research takes place that does not disconnect itself from the affections themselves, from life and from the existential territories (Romagnoli 20og). In this plane, an effort was made, therefore, to make flexible the dichotomies between subject-object, even knowing that designation as a researcher produces a position of an individual who delineates another identity and at times relations of knowledge and power. Nevertheless, it was through practices and encounters that emphasized an ethic and an aesthetic, as proposed by Guattari (1992), and not a scientism, that we sought to guide the perspective during our study.
} 
imaginaries. In this processuality, we affirm that this territory does not only singularize old bodies, bears, and fat men, but any body that is open to these other flows that move in these places. It is an opening to a process of singularization, which according to Guattari and Rolnik, would be

[...] a form of refusing all these forms of manipulation and of telecommand, refusing them to construct modes of sensibility, modes of relationship with the other, modes of production, modes of creativity that produce a singular subjectivity. An existential singularization that coincides with desire, with a taste for living, with a will to construct the world in which we are found, with the establishment of dispositifs to change the types of society, the types of values, which are not our own (Guattari \& Rolnik 2007: 22)

The old body, in this case, becomes an assemblage of enunciation, that is, it gains intelligibility and legitimacy in a field of heterogeneous flows that are constantly crossing, allowing infinite assemblages (Benevides 2009). Thus, we consider that the cartographic lines traced in our study can provide some clues about how these dissident bodies can be stylized, connected with other bodies and create possible ways of life in this world marked by norms and by processes of exclusion.

Translated by Jeffrey Hoff

Received: April 4, 2015

Approved: June 1, 2015

\section{Bibliography}

AMARAL, Marilia dos Santos. 2012. 'Essa boneca tem manual': práticas de si, discursos e legitimidadesnaexperiência de travestisiniciantes. Dissertação de mestradoemPsicologia, Universidade Federal de Santa Catarina, Florianópolis, SC.

BENEVIDES, Regina. 2009. Grupo: a afirmação de um simulacro. 2a. ed. Porto Alegre: Sulina / Editora da UFRGS.

BOZON, Michel. 2009. "Las encuestas cuantitativas em comportamientos sexuales: emprendimientos sociales y políticos, productos culturales, instrumentos científicos".Revista Sexualidad, Salud y Sociedad, 3: 154-170.

BRAH, Avtar. 2006. "Diferença, diversidade, diferenciação". Cadernos Pagu. 26: 329-376.

BUTLER, Judith. 1993. Bodies that matter: on the discursive limits of "sex". New York and London: Roudedge.

--_. 2002b. "Como os corpos se tornam matéria (entrevista com Judith Butler feita por Baukje Prins e Irene Costera Meijer)". Revista Estudos Feministas, 10(1): 155-167.

. 2003. Problemas de gênero:feminismo e subversão da identidade.Tradução de Renato Aguiar. Rio de Janeiro: Civilização Brasileira.

CARDOSO DE OLIVEIRA, Roberto. 1998. O trabalho do antropólogo. Brasília/ São Paulo: ParaleloQuinze/ Editora da Unesp.

CARDOZO, Fernanda. 2009. Das dimensões da coragem: socialidades, conflitos e moralidades entre travestisemumacidade no sul do Brasil. Dissertação de mestradoemAntropologia Social, Universidade Federal de Santa Catarina, Florianópolis.

CÓRDOVA, Luiz Fernando Neves. 2006. Trajetórias de homossexuaisnailha de santacatarina: temporalidades e espaços.Tese de DoutoradoemCiênciasHumanas, Universidade Federal de Santa Catarina, Florianópolis, SC. 
COSTA, Jurandir Freire. 1992. A inocência e o vício: estudossobre o homoerotismo. Rio de Janeiro: RelumeDumará.

DA MATTA, Roberto. 1978. “O ofício do etnólogooucomoterantropological blues”. In: Edson Nunes (org.), A aventurasociológica. Rio de Janeiro: Zahar. pp. 23-35.

DE BARROS, Laura Pozzana\& KASTRUP, Virgínia. 2009. “Cartografar é acompanharprocessos”. In: Eduardo Passos; VirgíniaKastrup;Liliana da Escóssia (orgs.), Pistas do método da cartografia. Pesquisa-intervenção e produção de subjetividade. Porto Alegre: Sulina. pp. 52-75.

DEBERT, Guita Grin. 1999. A reinvenção da velhice: socialização e processos de reprivatização do envelhecimento. São Paulo: Editora da Universidade de São Paulo/ FAPESP.

DELEUZE, Gilles. 2008. Conversações. Tradução de Peter PálPelbert. São Paulo: 34 . \& GUATTARI, Félix. 2009. Mil platôs - capitalismo e esquizofrenia - Vol. 1. Rio de Janeiro: Editora 34.

--_. 2010. O anti-Édipo - capitalismo e esquizofrenia I. Tradução de Peter PálPelbert. São Paulo: 34.

FONSECA, Cláudia. 1999. "Quando cada caso NÃO é um caso. Pesquisa etnográfica e educação". Revista Brasileira de Educação, 10: 58-78.

FOUCAULT, Michel. 1995. “O sujeito e o poder”. In: Hubert Dreifus; Paul Rabinow, Michel Foucault, uma trajetória filosófica: para além do Estruturalismo e da Hermenêutica. Rio de Janeiro: Forense Universitária. pp. 231-249.

--_. 1988. História da sexualidade - a vontade de saber. Vol. 1. São Paulo: Graal.

-_-. “Outros Espaços” (conferência). 2009. In: Ditos e Escritos Vol. III . $2^{\mathrm{a}}$ ed. Rio de Janeiro:

ForenseUniversitária. pp. 411-422.

--_. 2010. “O corpo utópico". In: El cuerpo utópico. Las heterotopías. Buenos Aires: Ed. Nueva Vision. Tradução: CEPAT, Fonte: IHU - InstitutoHumanitasUnisinos. pp.o7-18

FRANÇA, Isadora Lins. 2010. Consumindo lugares, consumindo nos lugares: homossexualidade, consumo e subjetividades na cidade de são Paulo. Tese de doutorado. Universidade Estadual de Campinas, Campinas.

GRUNVALD, Vitor. 2009. "Butler, a abjeção e seu esgotamento". In: Maria Elvira D. Benítez\& Carlos Eduardo Fígari (orgs.), Prazeres dissidentes. Rio de Janeiro: Garamond. pp. 31-68.

GUATTARI, Félix. 1992. Caosmose: Um novo paradigmaestético.Tradução de Ana Lúcia de Oliveira e

LúciaCláudia. São Paulo: 34.

. \& ROLNIK, Suely. 2007. Micropolítica: cartografias do desejo. 8a ed. Petrópolis, RJ: Vozes.

HALBERSTAM, Judith. 2005. In a Queer time and place: transgender bodies, subcultural lives. Nova York/Londres: Nova York University Press.

HENNING, Carlos Eduardo. 2008. As diferenças na diferença: hierarquia e interseções de geração, gênero, classe, raça e corporalidade em bares e boates gls de florianópolis, SC. Dissertação de mestradoemAntropologia Social, Universidade Federal de Santa Catarina, Florianópolis.

-_-. 2014. Paizões, tiozões, tias e cacuras: envelhecimento, meiaidade, velhice e homoerotismomasculinonacidade de São Paulo. Tese de doutorado, UniversidadeEstadual de Campinas, Campinas.

KASTRUP, Virgínia. 2009. "O funcionamento da atenção no trabalho do cartógrafo". In: Eduardo Passos; Virgínia Kastrup; Liliana da Escóssia (orgs.), Pistas do método da cartografia. Pesquisa-intervenção e produção de subjetividade. Porto Alegre: Sulina. pp. 32-51.

LIVESEY, Graham. Assemblage. In: PARR, Adrian (Ed.). The Deleuze Dictionary. Revised Edition. Edinburgh:

Edinburgh University Press, 2010.

MISKOLCI, Richard \& PELÚCIO, Larissa. 2008. "Aquele não mais obscuro negócio do desejo”. In: Nestor Perlongher (org.), O negócio do michê. A prostituição viril em São Paulo. São Paulo: Editora Fundação Perseu Abramo. pp. 09-32.

ORTEGA, Francisco. 2008. O corpo incerto - corporeidade, tecnologias médicas e cultura contemporânea. Rio de 
Janeiro: Garamond.

PERLONGHER, Néstor. 2005. “Territórios marginais”. In: James N. Green e Ronaldo Trindade (orgs.),

participação de José Fábio Barbosa da Silva [et al.], Homossexualismo em São Paulo e outros escritos. São Paulo: Editora UNESP. pp. 263-29o.

---. 2008. O negócio do michê. A prostituição viril em São Paulo. São Paulo: Editora Fundação Perseu Abramo. PERUCCHI, Juliana. 2001. Eu, tu, elas. Investigando os sentidos que mulheres lésbicas atribuem às relações sociais que estabelecem em um gueto GLS de Florianópolis. Dissertação de mestrado em Psicologia, Universidade Federal de Santa Catarina, Florianópolis.

POCAHY, Fernando Altair. 2011. Entre vapores e dublagens: dissidências homo/eróticas nas tramas do envelhecimento. Tese de doutorado, Universidade Federal do Rio Grande do Sul, Porto Alegre.

-_-. 2011b. "A idade um dispositivo. A geração como performativo. Provocações discursivodesconstrucionistas sobre corpo-gênero-sexualidade". Revista Polis e Psique, 1: 254-275.

PRECIADO, Beatriz. 2011. Multidões queer: notas para uma política dos “anormais”. Revista Estudos Feministas, 19(1): 11-20. Retrieved October 16, 2015, from http://www.scielo.br/scielo.php?script=sci_ arttext\&pid=S0104-026X2011000100002\&lng=en\&tlng=pt.

ROLNIK, Suely. 1997. “Uma insólita viagem à subjetividade”. In: Daniel Lins (org.), . Cultura e subjetividade: saberes nômades. Campinas/SP: Papirus. pp. 25-34.

ROMAGNOLI, Roberta Carvalho. 2009. "Cartografia e a relação pesquisa e vida”. Psicologia\&Sociedade, 21(2): 166-173.

SANTOS, Daniel Kerry. 2012. Modos de vida e processos de subjetivação na experiência de envelhecimento entre homens homossexuais na cidade de Florianópolis/SC.Dissertação de Mestrado em Psicologia - Curso de PósGraduação em Psicologia, Universidade Federal de Santa Catarina, Florianópolis.

___; LAGO, Mara Coelho de Souza. 2013. "Estilísticas e estéticas do homoerotismonavelhice: narrativas de si”. Sexualidad, Salud y Sociedad - Revista Latino Americana, 15: 113-147.

SILVA, Marco Aurélio. 2003. "Se manque!" Uma etnografia do carnaval no pedaço GLS da Ilha de Santa Catarina. Dissertação de mestrado em Antropologia Social, Universidade Federal de Santa Catarina, Florianópolis. SIMÕES, Júlio Assis. 2004. "Além da Barbie: outras imagens na cena homossexual contemporânea”. XXIV Reunião Brasileira de Antropologia, Olinda. Mimeo.

VENCATO, Ana Paula. 2002. "Fervendo com as drags": corporalidades e performances de drag queens em territórios gays da Ilha de Santa Catarina. Dissertação de mestrado em Antropologia Social, Universidade Federal de Santa Catarina, Florianópolis.

Daniel Kerry dos Santos

Graduate Program in Psychology, Centre of Philosophy and Human Sciences, Federal University of Santa Catarina, Florianópolis/SC, Brazil dakerry@gmail.com

\section{Mara Coelho de Souza Lago}

Interdisciplinary Graduate Program in Human Sciences, Centre of Philosophy and Human Sciences, Federal University of Santa Catarina, Florianópolis/SC, Brazil maralago7@gmail.com 